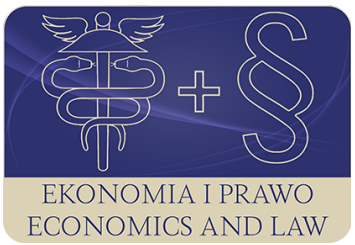

EKONOMIA I PRAWO. ECONOMICS AND LAW

Volume 15, Issue 3, September 2016

p-ISSN 1898-2255, e-ISSN 2392-1625

www.economicsandlaw.pl

ORIGINAL ARTICLE

received 01.12.2016; revised 24.01.2017; accepted 24.01.2017

Citation: Buszko, M., \& Krupa, D. (2016). Discussion about developing securitisation in Poland

with participation of securitisation investment funds. Ekonomia i Prawo. Ecomomics and Law, 15(3): 279-294. doi:10.12775/EiP.2016.018.

\title{
Discussion about developing securitisation in Poland with participation of securitisation investment funds
}

\author{
MICHAE BUSZKO \\ corresponding author \\ Nicolaus Copernicus University, Faculty of Economic Science and Management, Department \\ of Finance, ul. Gagarina 13A, 87-100 Toruń, Poland \\ $\square$ mibus@umk.pl

\section{DOROTA KRUPA} \\ Nicolaus Copernicus University, Faculty of Economic Science and Management, Department \\ of Finance, Poland \\ వdkrupa@umk.pl
}

\begin{abstract}
Motivation: The paper refers to the issue of development of securitisation in Poland. Securitisation is a multipurpose financial technique commonly used in many countries, especially in those with highly developed capital markets. Such technique supports assets and liabilities management, transfers risks as well as leads to creation innovative, assets-based securities. As Polish financial institutions, especially banks, are facing new

challenges related to regulatory capital, long-term financing, non-performing debts and taxation, we examine if securitisation may be developed and successfully used on Polish financial market. In the paper, we discuss the development securitisation in Poland, focusing on legal, financial and structural aspects.

Aim: the aim of the paper is to evaluate the conditions of using and developing securitisation in Poland with regard to performing as well as non-performing assets. We also evaluate the role and significance of securitisation investment funds, i.e. special type of investment funds operating in Poland, which are evaluated as the most suitable SPVs for securitisation.
\end{abstract}


Results: upon the research, we conclude that in Poland the most dynamically developing segment of securitisation is that based on non-performing debts, and its significance will be growing altogether with the growth and consolidation of Polish debt collection market. We also conclude that the major barrier related to development of this area of finance is a lack of precise legal and tax regulations.

Keywords: securitisation; loans; investment funds; Poland

JEL: G20; G21; G23

\section{Introduction}

Securitisation is a complex refinancing technique known from the late 1970s, which allows to convert cash flows and risks from homogenous pools of illiquid financial assets, into marketable securities. Securitisation requires at least three types of participants, i.e. originator whose assets are separated and usually transferred out of the balance sheet, a special purpose vehicle (SPV) which is responsible for purchasing assets, managing the risk and issuing securities as well as investors purchasing securitisation based securities (usually bonds or certificates of investments). In such transaction, the risk of underlying assets is removed from the balance sheet of the originator and then through special purpose vehicle structured and passed to the capital market. By using of such financial technique banks, non-bank companies as well as investors may obtain several substantial benefits in scope of financial management and efficiency.

The natural environment to use securitisation is banking industry and other financial services generating long-term recurring cash flows and characterised by homogenous risk. The development of securitisation and its instruments requires generally a large and deep contractual debt market as well as developed capital market. In practice, securitisation can be conducted using either performing or non-performing debts and in the latter case it is commonly treated as the truly effective technique of managing and structuring the risks of debts overdue.

In Poland, a sufficient supply of non-bank deposits and other traditional financing instruments, relatively high liquidity of the banking sector as well as conservative credit policy of banks discouraged banks from conducting securitisation of assets of a high quality. Lack of precise legal regulation of securitisation itself as well as unclear tax interpretation limited the use of such technique to several deals with capital companies serving as SPVs. In contrary, the dynamic development of securitisation was noted in the segment of credits overdue with the leading role played by regulated and supervised by Polish Financial Supervision Authority securitisation investment funds.

The goal of the paper is to discuss the conditions of functioning and developing of securitisation in Poland with a special regard to securitisation investment funds which function as special types of SPVs. In the paper, we present discussion about general use of securitisation, we characterise benefits and costs of securitisation in accordance with its performance in Poland. Furthermore, 
we present legal environment of conducting securitisation in Poland by banks and securitisation investment funds as well as we characterise development of securitisation based on performing and non-performing loans. We also discuss general prospects of development of securitisation with participation of investment funds. Our considerations are further discussed in the next paper in this subject entitled 'Characteristics and prospects of development of securitisation investment funds market in Poland'.

\section{The characteristics of the subject of research and literature review}

Based on the practice of structured finance, the securitisation can be considered as a multipurpose financial technique used for reducing funding costs, diversifying capital sources, managing various types of risks, meeting regulatory capital requirements, managing assets and liabilities and generating fee incomes. Such technique has a high quantitative significance and it can be considered as fundamentally changing capital markets and financial intermediation as well as challenging many theories of the role of intermediaries (Gorton \& Metrick, 2012 , p. 1). It can be used by various groups of entities such as financial institutions, non-financial companies as well as state or local governments (Fabozzi \& Kothari, 2008, pp. 13-21).

As a rule, securitisation allows to convert homogenous pools of illiquid assets, mostly receivables, retail or mortgage loans or debt instruments into rated marketable securities (mostly bonds or investment certificates) ready to trade on the capital market. In fact, today's practice of securitisation reveals that such a technique can be based on many other types of sophisticated assets such as: highly leveraged debts, corporate loans and bonds, structured products, securitisation based securities, commodities, equity and various types of cash flows such as future cash flows from whole business operations. Investors participating in securitisation acquire rights linked to the selected group of assets and their cash flows but not obligation characterising traditional debt instruments (Kendall, 2000, p. 2). Consequently, they gain the exposure to the unique type of risk, which is not available in the traditional capital market products (Fabozzi et al., 2006, p. 65). In fact, securitisation of homogenous assets allows to structure the risk to offer tranches of securities of various seniorities and credit ratings. E.g. securitisation of non-performing loans may bring securities with investment grade AAA (Kothari, 2006, p. 66). Such structuring requires various credit enhancements (Lockwood et al., 2001, p. 29) and participation of entities taking the remaining risk, especially of not rated securities.

As the transactions of securitisation in the last years were strongly supported by development of financial engineering and derivatives markets, especially credit default and total return swaps, the technique under consideration started to be performed without physical transfer of assets. Its character evolved then from traditional to synthetic, including sub-participation, allowing to keep se- 
curitised assets in the balance sheet of the originator (KNB, 2007, p. 7). That solution brought new ways and possibilities of using of securitisation, by transfer of risk through credit default swaps (CDS) but without influencing the assets (Waszkiewicz, 2011, p. 60). The synthetic securitisation thanks to the transfer of credit risk through derivatives became more flexible than traditional off-balance technique but at the same time less transparent for evaluation of total risk and financial effectiveness (Buszko, 2009).

The crucial aspects of securitisation are types and characteristics of financial instruments issued in its processing. Due to obtaining major benefits from securitisation based on long-term recurring cash flows, the technique is particularly useful to implement in the banking or financial industry. Its instruments (bond or certificates of investments) are then commonly embodying risks of homogenous pools of bank loans (mortgages) or leasing receivables. Such instruments are then labelled as MBS (Mortgage Backed Securities) or ABS (Asset Backed Securities) depending on the type of underlying assets. The more complex and risk structured securitisation products are labelled as CDO (Collateralized debt obligation). Within groups of MBS, ABS and CDOs one can find many subcategories representing individual type of securitized assets (RMBS, CMBS, LBS, CBO, CLO, CCO, CSO, CXO, CEO, CDO2, WBS, SME). The potential of development of securitisation instruments can be evaluated as unlimited (Waszkiewicz, 2004, p. 18).

Regarding all the features of transactions of securitisation, its advantages and limits, such a technique is nowadays considered in UE as a solution, which reduces the dependence of the European economy and its growth onto of financial condition and credit policy of banks. Due to strong negative consequences of financial distress of commercial banks in many EU countries (especially Ireland, Great Britain, Germany, Denmark, France and Spain) at the EU level there have been started legislative works to support restoration of a high quality and safe securitisation market as an alternative to bank financing. The purpose of such works was to create legal environment enhancing using securitisation as an alternative source of financing in Europe based on specified STS (simple, transparent and standardised) transactions (European Commission, 2015). Securitisation started to be considered as one of the tools supporting an increase of competitiveness of the European economy with the final effect of achievement of sustainable growth and job creation. The core idea related to works at EU level was to prepare regulations referring to securitisation which would eliminate such mistakes in its using as before subprime crisis.

\section{Methods}

The paper was based upon the study of literature on securitisation, analysis of cases of securitisation transactions and evaluation of securitisation investment funds market. An early stage of Polish securitisation market as well as 
a lack of publicly accessed financial data influenced the use of qualitative methods of research during preparing the paper.

In the paper, we provide qualitative analysis of the process development of securitisation in Poland, we examine thoroughly legal conditions of conducting securitisation in Poland, especially the Banking Act of 1997 and Act on Investment Funds and Management of Alternative Investment Funds of 2004. We evaluate also the terms and conditions of transactions and point out reasons for implementing securitisation in Poland. Finally, we appraise the development of securitisation on the background of growth of debt collection market.

\section{Results}

\subsection{Legal aspects of securitisation in Poland}

Securitisation is neither defined nor specially regulated by Polish law. That means such technique is conducted according to various acts. Some direct links to the securitisation are in the Banking Law (1997) and Act on investment funds and management of alternative investment funds (2004). Apart from the mentioned acts, securitisation is indirectly regulated by financial or civil law including Act on bonds (2015), and the Civil Code (1964).

The banking law allows banks to conclude contract of assignment of receivables or contract of sub-participation with investment fund company (IFC) managing the securitisation fund or directly with the securitisation fund. Bank can also assign receivables to other entity (capital company), to issue securities backed by securitised receivables. The issuing entity mustn't have any organisational nor capital relationship with the bank and the core of its business shall be purchasing of receivables and issuance of securities or activities related to such processes. The banking law orders banks to keep registry of the receivables, which are used for the contract of sub-participation. Banks can use credit derivative or other than assignment or sub-participation agreements to transfer entire or some part of the risk onto other entity. Banks can pass the information being a banking secrecy if the information is required for assignment (true sale) or sub-participation of receivables, to obtain credit rating, to service securitised receivables, to arrange and conduct issuing of securitisation-based securities or to insure against the risk of default of debtors whose receivables were securitised.

Apart from the Banking law the legal regulations related to processes of securitisation are included in the Act on investment funds and management of alternative investment funds. The scope of such regulations in general confirms the preference of Polish legislator of conducting securitisation with the participation of investment funds as SPVs (Krupa, 2008, pp. 112-115)1. Investment

1 The securitisation investment fund is the only type of SPV allowed to enter sub-participation agreements in the securitisation transactions. 
funds established for securitisation purposes are legally extracted and named securitisation investment funds. The securitisation investment funds are designated to purchase receivables including public finance receivables and rights to provisions from receivables as well as to issue certificates of investments. According to the mentioned act a securitisation fund can be set-up only as standardised or non-standardised closed-end investment fund. The standardised investment fund shall be established as an umbrella fund (with separated sub-funds) $)^{2}$. Such fund is obliged to invest at least $75 \%$ of the asset value of a given sub-fund into single pool of receivables and/or the rights to total income received from single pool of receivables. The securitisation fund cannot issue following series of certificates of investment related to a given sub-fund. If the statute of standardised securitisation fund allows, the fund can allocate more than $75 \%$ of assets of a given sub-fund in several pools of receivables or rights to total income received from more than one pool of receivables under the condition that the originators of the securitisation are domestic banks, credit institutions or credit cooperatives, the receivables in all of the pools are homogenous by the type and the transfer of receivables is made up to 3 months after establishment of the fund. The non-standardised securitisation fund is a fund obliged to invest not less than $75 \%$ of its total assets, and in the case of a non-standardised securitisation umbrella fund of not less than $75 \%$ of the assets of each subfund, in: specific receivables, securities incorporating receivables (up to 25\% of net assets value of the fund or each of the sub-funds), rights to income from specific receivables. The participants of the non-standardised securitisation funds are as a rule institutions, i.e. legal persons or organisational entities not being legal persons ${ }^{3}$.

In general, the investments of securitisation funds, apart from receivables and rights from receivables, are limited to: debt instruments, shares in money market funds, bank or credit institutions deposits, money market instruments and derivatives. Such investments are allowed only for reduction of the level of investment risk of the fund. Moreover, securitisation funds can neither give loans nor provide sureties or guaranties. Under some circumstances they are allowed to issue bonds ${ }^{4}$.

The securitisation investment fund may purchase performing or non-performing receivables, however the exposure to single entity risk is limited to $20 \%$ of the assets of the fund.

2 Such condition is not obligatory for non-standardised investment fund, which may be set up as an umbrella fund.

3 The statue of the securitisation fund may allow natural persons to purchase investment certificates of the fund but the issuing price of the certificate cannot be lower than 40.000 EUR.

${ }^{4}$ Up to $25 \%$ of assets for standardised fund and $75 \%$ in case of non-standardised, only when statute of the fund allows for bond issuing and the meeting of investors of the fund is established. 
The management of the securitised receivables of the fund is allowed by the third party (i.e. servicer) however such entity must obtain license of Polish Financial Supervisory Authority. The servicer must manage the securitised receivables based on fair dealing rules and properly assuring the interests of participants of the fund ${ }^{5}$.

The securitisation investment funds are privileged in the process of a true sale of receivables, when they are charged concessionary fee (100 PLN) for register of the transfer of mortgages and registered pledge.

One of the most important features of conducting securitisation based on securitisation investment funds is exemption of funds from corporate income tax. Moreover, Polish tax law allows to get tax benefits by banks if they participate in the securitisation with securitisation investment funds as SPVs. Such tax benefits are not available to other type of originators.

\subsection{Securitisation based on performing assets}

The market of securitisation of performing assets is very shallow and limited to 1-2 high value transactions per year. So far there were just several entities conducting such transactions, i.e.: Utrica Zaopatrzenie Farmaceutyczne SA (securitisation of receivables from sales of pharmaceuticals, PLN $50 \mathrm{mln}$ in 1999), Pekao Leasing Sp. z o.o. (leasing receivables, PLN $4.3 \mathrm{mln}$ in 2000), Pharmag SA (trade receivables, PLN $100 \mathrm{mln}, 2001$ ), Dominet Bank SA (car loans, PLN $600 \mathrm{~m}$ in 2006), Raiffeisen-Leasing Polska SA (leasing receivables PLN 640m in 2006, PLN 360m in 2008, PLN 950m in 2014, PLN 525m in 2015), Raiffeisen Bank Polska SA (SME loans, EUR 270m in 2006) ${ }^{6}$, Millennium Leasing Sp. z o.o. (leasing receivables, PLN 850m in 2007), Getin Noble Bank SA (car loans, PLN 1 bn in 2012, leasing receivables PLN 1.9 bn in 2015), Santander Consumer Bank SA (retail and car loans PLN 1.751 bn in 2014 and instalment loans PLN 1.26 bn in 2015). Some of the transactions, including Raiffeisen Leasing and Getin Noble Bank were arranged in programs. The characteristic feature of the transactions completed after 2004, i.e. joining EU by Poland was a participation of foreign commercial banks as well as support international financial institutions, such as European Investment Bank, European Investment Fund and European Bank for Reconstruction and Development ${ }^{7}$. The motives indicated by the originators of the mentioned transactions were as follows: reduction costs of financing, increasing of transparency of assets, improvement of monitoring of quality of assets, adjustment of maturity of assets and liabilities, increasing long-term liquidity and capital stability as well as an access to the new sources of financing.

5 The most commonly the role of the servicer is played by the debt collection company or the originator of the securitisation (bank).

6 That was the first synthetic securitisation transaction conducted in Poland.

${ }^{7}$ An involvement of the mentioned institutions was to promote and support financing of SME through securitisation. 
Upon the analysis of the literature, reports and information published by financial institutions that conducted securitisation in Poland, one may find major reasons determining a small number of transactions based on bank regular debts. They are as follows:

1. Lack of precise legal and tax regulations. As there is no precise definition of securitisation, its structuring and standardising in Polish law system, financial institutions are reluctant to apply the technique, which might turn out problematic and exposing them or SPVs onto substantial legal risk.

2. Unclear interpretation of VAT and CLAT taxes for securitisation. Transactions of securitisation are not defined in Polish tax law what makes their tax interpretation variable and dependent on the individual decision of local tax offices.

3. Lack of tax-neutrality of transfer of performing assets to SPV. This condition becomes particularly problematic in case of transfer of high quality assets, as the eventual loss on their sale is not tax deductible.

4. The necessity of making the up-front payment when using sub-participation agreement. The condition of full up-front payment made by SPV, i.e. securitisation investment fund, is difficult or practically unable to meet when securitising performing loans. In this case SPV needs to gather from the beginning of its functioning a high value of funds from investors.

5. Lack of regulations and administrative system of supporting low-cost and short-term legal transfer of mortgages in the land registry.

6. Lack of pricing and tax regulations for the period of legal transferring the assets in case of rejections of the transfer by court or repayment of loans during the process of transferring.

7. Low level of development of primary and secondary capital market for securities based on securitised assets. Such condition limits the efficiency of transferring the high-quality assets due to expectation of increased premiums.

8. A relative high quality of mortgages in Poland linked with a good access to traditional sources of financing of bank activities (non-bank deposits, interbank loans, issuing of bonds) do not motivate banks to sell assets to SPVs with a discount on the face value.

9. Bad reputation of securitisation observed during the subprime crisis discouraged banks in Poland from developing this technique. The single transactions in Poland were conducted shortly before (2006-2008) and then several years after the crisis (2012-2015).

\subsection{Securitisation based on non-performing assets}

In opposite to transactions based on regular assets, since 2004, i.e. the year of implementing new Act on investment funds, one may observe dynamic development of securitisation based on non-performing debts and conducted by securitisation investment funds established upon the mentioned act (UKNF, 2013, 
p. 6) ${ }^{8}$. The growth of importance of such type of securitisation was strongly supported by the development of the investment fund sector and searching for new investment opportunities by the investors as well as by the maturing and growth of debt collecting services market. The securitisation of non-performing debts become characteristic in the Polish capital market with the central role of securitisation investment funds. At the end of May 2016 there were registered 97 securitisation funds in Poland offered by twenty-five IFCs and their net assets value reached PLN 5.7 bn (approximately EUR $1.3 \mathrm{bn}$ ). The precise data related to this segment of capital market as well its evaluation is presented in the next paper entitled 'Characteristics and prospects of development of securitisation investment funds market in Poland'. Upon the analysis of legal regulations, data obtained from statutes of securitisation investment funds as well as analysis of performance of such funds one may identify major determinants of developing securitisation with participation of securitisation investment funds as SPVs. They are as follows:

1. The process of securitisation with the participation of securitisation investment funds is relatively precisely regulated by Polish law, what reduces the overall legal risk of the transactions. That naturally inclines to develop the transactions in the sector of securitisation investment funds (based on non-performing debts).

2. The securitisation investment funds are commonly linked with debt collection companies, which are on the one hand arranging the assets for the transactions and on the other hand function as the servicers of the debts. Such structuring facilitates the process of transaction.

3. The securitisation investment funds are the only type of SPVs allowed to sign sub-participation agreements.

4. The securitisation investment funds are exempted from the payment of CIT, what differentiates them from SPVs functioning as capital companies 9

5. Transactions of banks and the securitisation investment funds based on non-performing assets allow to get tax benefits in the process of their transfer (up to the value of provisions related to such assets).

6. The functioning of securitisation investment fund is more transparent than other types of SPV and supervised by Polish Financial Supervisory Authority. Such condition increases the quality and safety of the whole transaction of securitisation.

Securitisation conducted by the securitisation investment funds (based on non-performing loans) brings several vital benefits for various groups of participants (table 1$)$.

8 Act on investment funds of 2004 introduced category of securitisation investment funds.

9 At the time of preparing the paper there were proposals of introducing taxation (CIT) on all closed-end funds in Poland. 


\subsection{Debt collection market as a base for securitisation in Poland}

The development of securitisation by securitisation investment funds in Poland is strictly related to growing and maturing of debt collection market. Such market with sales of assets discounted by more than $90 \%$ of the face value has become a place of benefits for all participants of securitisation (debt collection companies, investment funds and originators $)^{10}$. In general, a participation in this market can generate profits due to more effective and time saving processes of debt collecting provided by debt collection companies and securitisation funds, while banks may remove from their balance sheets problematic assets.

Up to date, the market of debt collection is developing fast in Poland and at the end of 2015 reached the value of PLN 74.5 bn (chart 1) what was more by $360 \%$ comparing to year 2010, i.e. the first year after subprime crisis (KPF, 2016).

The annual dynamics of growth of the market in the mentioned period was not lower than $20 \%$, what may confirm its rising significance in the financial market in Poland (chart 2).

In 2015 (Q3) the face value of assets under management of debt collection companies reached PLN 55.3 bn what was approx. 83\% of all assets of the market of PLN 66.9 bn (KPF, 2016). The major share of non-performing assets is in possession of securitisation investment funds belonging to the groups of debt collection companies, which established those funds. In the mentioned period, they counted PLN 40.0 bn (accordingly to the face value), what was $72 \%$ of a face value of total assets belonging to all securitisation funds. The remaining PLN 15.300m was in possession of other securitisation funds. In the latter case, within last several years one can observe very dynamic growth of the value of assets, which reached 300\% comparing to 2014 (Q3). The characteristic feature become cooperation of debt collection companies with other than own securitisation funds. The share of companies which were involved in the management of assets of own securitisation investment funds 2015 (Q3) amounted to 64\%, while $57 \%$ companies did it for other funds (KPF, 2016). The relative number of companies managing debts for other than own securitisation investment funds substantially increased by approx. 97\% from 2014 and by 170\% from 2013. The latest phenomenon observed in Poland in scope of functioning of securitisation investment funds is also development of multi funds servicing by single debt collection companies. The cooperation with funds established by debt collection companies being competitors increases the effectiveness of debt collecting without the necessity of new organisational investments, confirms the raising standards of such process as well as inclines to consolidation of the whole sector.

10 Their detailed list is presented in table 1. 


\subsection{Perspectives of development of securitisation in Poland with participation of securitisation investment funds}

The change of the legal and economic terms of functioning of commercial banks in Poland, the necessity for increasing effectiveness of business processes as well as a high potential to get profits from Polish debt collection markets are the major aspects determining future development of securitisation in Poland.

The relatively low capitalization of Polish banks against banks in Europe, imposing tax on assets of financial institutions in 2016, maturing of portfolios of loans in the banking sector, especially mortgages, as well as unsolved question of Swiss franc mortgage loans will be pushing banks to manage their assets in more effective way, including sales of less efficient or not-performing assets. Moreover, the accumulation and maturing of debts in Polish economy being a consequence of its growth will increase the base for securitisation, especially in segment of debts overdue. As market of securitisation investment funds is getting bigger and more matured, it becomes also more trustworthy and attracting new investors including foreign debt collection companies. The possibility of fast refinancing of problematic assets, especially non-performing debts, should enhance rather to a true sale instead of ordering of servicing them by debt collection companies. Such condition seems to be particularly important in case of bank loans after abolishing in Poland in 2016 the legal privilege of banks in collecting debts through bank enforcement title.

As in Poland the securitisation investment funds are the most transparent and precisely regulated entities, which perform function of SPV, securitisation conducted with their participation should remain relatively stable and safe. As the funds deal primarily with low quality assets, they get more experience in effective risk management and receivables valuation. Such factor counteracts the improper structuring of transactions as well as bad pricing of certificates of investment.

The further development of securitisation investment funds shall be characterised by consolidation of the debt collection market, what is already reflected by cooperation of individual debt collection companies with multiple funds. As the competition on this market will be increasing and new participants (especially foreign entities) will appear, the pricing of debts will be under pressure. One may expect then the further consolidation of the debt collection market.

\section{Conclusion}

Upon the evaluation of the nature of transactions of securitisation, their legal regulations in Poland as well as their development in Poland we may draw several conclusions.

Securitisation upon the performing loans or other low risk receivables is used occasionally in Poland despite a relatively high value of assets eligible for 
such technique. The reasons of this phenomenon come from law and taxation as well as availability of traditional sources of financing.

The dynamic development of securitisation is observed in sector of securitisation investment funds, which are dealing with non-performing debts. The crucial factor in this field plays detail legal regulation of their functioning as well as tax privileges (lack of CIT payment, possibility of tax deduction in case of sale non-performing loans).

There are significant legal barriers limiting the development of securitisation in Poland. The most important barriers are those related to legal transfer of mortgages and taxation of transactions based on sub-participation. The lack of administrative mechanisms supporting fast and effective transfer of rights related to real property as well as the moments of recognition of revenue and costs in sub-participation agreement will be discouraged the securitisation based on mortgage loans.

The development of debt collection market will be positively influencing the development securitisation of non-performing loans altogether with searching for improving operational results by banks, through outsourcing of debt collection. The factors supporting this thesis is more flexible and experienced way of collecting debts by external entities, searching for new regulatory capital and tending to increase effectiveness of assets in terms of low interest rates.

\section{References}

Buszko, M. (2009). Sekurytyzacja syntetyczna oraz syntetyczne produkty CDO. In P. Karpuś, \& J. Węcławski (Eds.), Rynek finansowy w erze zawirowań. Lublin: Wydawnictwo UMCS.

European Commission. (2015). Proposal for a regulation of the European Parliament and of the Council lying down common rules on securitisation and creating a European framework for simple, transparent and standardised securitisation and amending Directives 2009/65/EC, 2009/138/EC, 2011/61/EU and Regulations (EC) Nol060/2009 amd (EU) No 648/2012 (COM(2015) 472).

Fabozzi, F.J., \& Kothari, V. (2008). Introduction to Securitisation. Hoboken: John Wiley \& Sons. doi:10.1002/9781118266892.

Fabozzi, F.J., Davis, H.A., \& Choudhry, M. (2006). Introduction to Structured Finance. Hoboken: John Wiley \& Sons. doi:10.1002/9781119197249.

Gorton, G., \& Metrick, A. (2012). Securitization. NBER Working Paper Series, 18611. doi:10.3386/w18611.

Kendall, L.T. (2000). Securitization: A new Era in American Finance. In L.T. Kendall, \& M.J. Fishman (Eds.), A Premier on Securitization. Cambridge: MIT Press.

KNB. (2007). Sekurytyzacja $w$ krajach Unii Europejskiej oraz $w$ polskim systemie bankowym. Wyniki ankiety badawczej. Retreived 15.09.2016 from https:// www.knf.gov.pl. 
KPF. (2016). Wielkość polskiego rynku wierzytelności zarządzanego przez członków KPF. Retreived 20.10.2016 from https://kpf.pl.

Kothari, V. (2006). Securitisation. The Financial Instrument of the Future. Singapore: John Wiley \& Sons. doi:10.1002/9781118390429.

Krupa, D. (2008). Zamknięte fundusze inwestycyjne. Warszawa: CeDeWu.

Lockwood, B.M., Mond, D., \& Fabozzi, F.J. (2001). The Anatomy of a Securitisation. In F.J. Fabozzi (Ed.), Accessing Capital Markets through Securitisation. New Hope: Frank J. Fabozzi Associates.

UKNF. (2013). Raport z prac grupy ds. sekurytyzacji wierzytelności bankowych. Retreived 15.11.2016 from https://www.knf.gov.pl.

Ustawa z dnia 15 stycznia 2015 r. o obligacjach [Act of January, 152015 on bonds] (Dz.U. 2015 poz. 238) (Poland).

Ustawa z dnia 23 kwietnia 1964 r. - Kodeks cywilny [Civil Code of April 23, 1964] (Dz.U. $1964 \mathrm{nr} 16$ poz. 93) (Poland).

Ustawa z dnia 27 maja 2004 r. o funduszach inwestycyjnych i zarządzaniu alternatywnymi funduszami inwestycyjnymi [Act of May 27, 2004 on investment funds and management of alternative investment funds] (Dz.U. $2004 \mathrm{nr} 146$ poz. 1546) (Poland).

Ustawa z dnia 29 sierpnia 1997 r. - Prawo bankowe [Banking Law of August 29, 1997] (Dz.U. 1997 nr 140 poz. 939) (Poland).

Waszkiewicz, A. (2004). 'Papierowe' bogactwo sekurytyzacji, Bank i Kredyt, 35(4).

Waszkiewicz, A. (2011). Ryzyko sekurytyzacji a kryzys finansowy. Warszawa: Oficyna Wydawnicza SGH.

\section{Acknowledgements}

Author contributions: authors have given approval to the final version of the article. Authors contributed to this work as follows: D.K. and M.B. developed the concept and designed the study; D.K. and M.B. collected the data; D.K. and M.B. analysed and interpreted the data; D.K. and M.B. prepared draft of article; D.K. and M.B. revised the article critically for important intellectual content. 


\section{Appendix}

Table 1.

\section{Benefits of securitisation of NPL with securitisation investment funds}

\begin{tabular}{|c|c|}
\hline Beneficiary & Benefits \\
\hline \multirow{7}{*}{$\begin{array}{l}\text { Investment } \\
\text { fund } \\
\text { company }\end{array}$} & enrichment of the investment offer not correlated to traditional capital market \\
\hline & obtaining additional source of income \\
\hline & getting earnings and experience in scope of trade of debts \\
\hline & possibility of setting up sub-funds and developing sophisticated investment strategies \\
\hline & developing relations with banks for long-term funding \\
\hline & developing offers of alternative investments \\
\hline & meeting sophisticated investment needs of investors through structuring \\
\hline \multirow{10}{*}{ Originator } & $\begin{array}{l}\text { securitisation funds are the only regulated structures that enable securitisation of non-performing } \\
\text { assets in the banking sector }\end{array}$ \\
\hline & obtaining tax benefits due to sales of low quality assets \\
\hline & liquidation of non-performing or unwanted assets \\
\hline & possibility of refinancing of core operations \\
\hline & increasing profits through reduction of provisions for non-performing assets \\
\hline & increasing profitability ratios (ROA, ROE) \\
\hline & possibility of restructuring of assets \\
\hline & matching maturity of assets and liabilities \\
\hline & reduction of costs of financing \\
\hline & saving costs, time and other resources due to outsourcing of collection of debts overdue \\
\hline \multirow{4}{*}{ Investor } & obtaining return on investment not correlated with capital market return \\
\hline & possibility of obtaining regular fixed income \\
\hline & diversification of investor's portfolio through certificates of securitisation fund \\
\hline & possibility of individual investment in receivables through securitisation fund \\
\hline
\end{tabular}

Source: own preparation. 


\section{Chart 1.}

Debts under management of debt collection companies in Poland (billions PLN)11

80

74.5

70

60

50

40

30

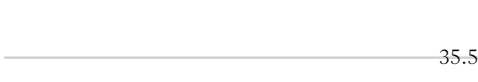

20

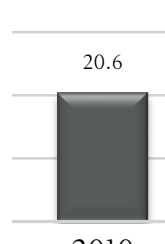

27.5

10

0

2010

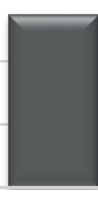

2011

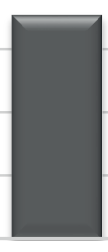

2012
56.9

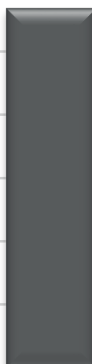

2014

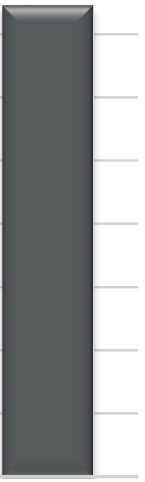

2015

Source: own preparation based on KPF (2016).

\section{Chart 2.}

The growth rate of market of debts under management of debt collection companies in Poland (in \%)

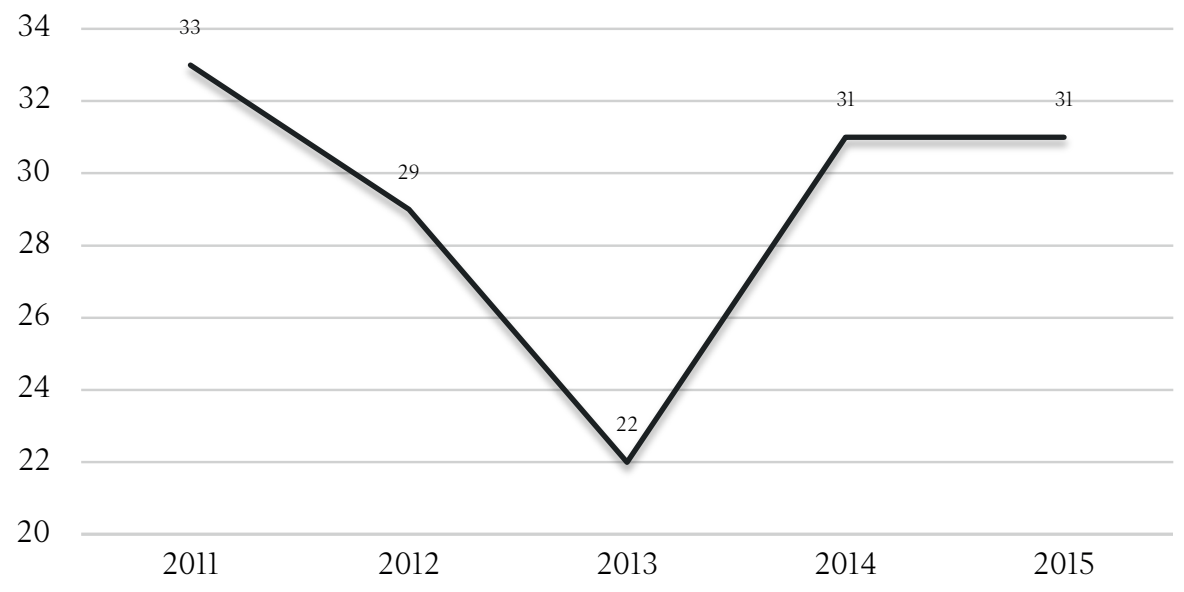

Source: own preparation based on KPF (2016).

11 The market of debts under management contains data from the companies affiliated to the Conference of Financial Companies in Poland (Konferencja Przedsiębiorstw Finansowych w Polsce). There are several dozen financial institutions belonging to the conference, including 27 leading debt collection and debt management companies. 
